\title{
Codonoboea oreophila (Gesneriaceae), a new species from Peninsular Malaysia
}

\author{
C.L. $\operatorname{Lim}^{1,2}$, R. Kiew ${ }^{1}$, N.W. Haron ${ }^{2}$
}

Key words

Codonoboea

Gesneriaceae

new species

Peninsular Malaysia
Abstract A new species of Codonoboea from Gunung Stong, Kelantan, Peninsular Malaysia, is described and illustrated.

Published on 23 August 2013

\section{INTRODUCTION}

A species of Gesneriaceae has been collected in Gunung Stong State Park by various collectors since 1924. It is found in montane forest on the highest peak, Gunung Stong (N5 ${ }^{\circ} 20^{\prime} 19^{\prime \prime}$, E101 '56'28"; alt. $1434 \mathrm{~m}$ ) and on other nearby peaks, such as Gunung Tera at $1176 \mathrm{~m}$. Kiew (1992) pointed out that it was a new species in Didymocarpus sect. Boeopsis (Ridley 1923) and suggested 'oreophila' as the species epithet. However, in the absence of flowers, the species was not formally described. In July 2008, flowering plants were collected and several unique characters of the flowers confirmed its status as a species new to science and that it is different from the other species in the section Boeopsis by its long corolla tube and the presence of pale yellow nectar guides.

All species in Didymocarpus section Boeopsis have now been transferred to Codonoboea (Kiew \& Lim 2011). Among Codonoboea species, C. oreophila Kiew ex C.L.Lim most resembles C. pumila (Ridl.) C.L.Lim and C. rubiginosa (Ridl.) C.L.Lim. All three have a rosette of thick succulent leaves that are densely silky hairy above, with leaf size ranging from $3-6$ by $1.6-3$ $\mathrm{cm}$. However, it is distinct from these two species by having oblanceolate leaves sometimes with a cordate and unequal base, narrower bracts (to $0.3 \mathrm{~mm}$ wide), single flowers and a longer corolla with two nectar guides (Table 1) and is here described as a new species.

\section{Codonoboea oreophila Kiew ex C.L.Lim, sp. nov. - Fig. 1}

Diagnosis: Codonoboea pumila simillima, habitu foliorum indumento, sed inflorescentiis unifloris (1-)2-floris in C. pumila, 2-12-floris in C. rubiginosa) corollis longioribus angustioribusque c. 15.5-18.8 $\mathrm{mm}$ longis (usque ad 7 $\mathrm{mm}$ in C. nana et C. rubiginosa) differt. — Typus: Lim et al. FRI 56646 (holo $\mathrm{KEP}$; iso E, K, L, SING), Peninsular Malaysia, Kelantan, Gunung Stong State Park, Gunung Stong, 1231 m alt., N5²0'25", E101²6'57", 26 July 2008.

Etymology. From its habitat, because it is only found in montane forest.

Rosette herb. Indumentum of uniseriate, multicellular (about 2-3(-5)-celled), very fine, translucent, eglandular hairs on young stem, petioles and upper lamina surface, more or less appressed near margin, on lower lamina surface more erect and

\footnotetext{
${ }_{1}^{1}$ Forest Research Institute Malaysia, 52109 Kepong, Selangor, Malaysia; corresponding author e-mail: limchunglu@frim.gov.my.

2 University of Malaya, 50603 Kuala Lumpur, Malaysia.
}

longer on veins beneath; fine, dark purplish maroon on peduncle, pedicel and calyx; very fine, to $0.3 \mathrm{~mm}$ long on corolla outside, corolla lobes short ciliate. Stem branched, (2-3-)6.5$9(-11) \mathrm{cm}$ long, 1.4-3.8(-7) mm thick, woody, base of stem often creeping, sometimes producing an elongated semi-woody side branch to $8.2 \mathrm{~cm}$ long, $1.7 \mathrm{~mm}$ thick, pale green in life. Flowering at c. $2.5 \mathrm{~cm}$ tall. Upper internodes crowded, lower internodes $5-9 \mathrm{~mm}$ long, sometimes to $2.5-3.5(-4.6) \mathrm{cm}$ in the elongated side branch. Leaves decussate; sessile in young leaves, petioles to (0.5-)1.5-2.4(-3.2) cm long, succulent, broadly grooved above in mature leaves; lamina oblanceolate to oblong, $3-4.8(-6)$ by $1.6-2.2(-3.1) \mathrm{cm}$, in life dark green above, brownish to greyish green beneath, drying greyish to greenish brown above, paler beneath, succulent in life, drying thickly leathery; base rounded to broadly cuneate, sometimes cordate, often unequal, margin crenulate, teeth c. 6-8 per $\mathrm{cm}$, teeth towards the apex often slightly overlapping the one behind, apex broadly obtuse to rounded; midrib grooved above, prominent beneath, lateral veins to 9-12 pairs, lower pairs almost parallel, upper pairs sharply arching to apex, obscure above, prominent beneath, intercostal veins inconspicuous. Inflorescences 1(-2) per axil, 1-flowered. Peduncle slender, (4.4-)5.8-6.6(-9) cm long, erect, with flower held above leaves, dark purplish maroon, apex bent and pointing downwards in bud, upon flowering becoming horizontal. Bract pairs opposite or subopposite, ligulate, c. $0.8-1.7$ by $0.3 \mathrm{~mm}$. Pedicel slender, (0.8-)1.2-1.5 cm long, concolourous with peduncle. Flowers held horizontally; calyx dark purplish maroon, free to base, lobes broadly oblong, apex acute, $1.5-2.4$ by $0.8 \mathrm{~mm}$, lower lobes slightly longer; corolla trumpet-shaped, to $19 \mathrm{~mm}$ long, c. $10 \mathrm{~mm}$ wide at mouth, pale lilac, darker on lower and lateral corolla lobes, with streaks of darker purple outside, tube white inside with 2 light yellowish nectar guides near mouth, tube to $10 \mathrm{~mm}$ long, $4 \mathrm{~mm}$ wide, narrower at base (c. $2 \mathrm{~mm}$ wide), corolla lobes 5 , apex rounded, upper lobes c. 4 by 3 $\mathrm{mm}$, reflexed, lateral lobes c. 5 by $6 \mathrm{~mm}$, lower lobe c. 5 by $5 \mathrm{~mm}$, lateral and lower lobes spreading from base; stamens with filaments white, filiform, c. $3 \mathrm{~mm}$ long, $0.2 \mathrm{~mm}$ wide at base, joined to corolla tube c. $4.1 \mathrm{~mm}$ from base, slightly bent at base, straight above, anthers white, reniform, c. 0.5 by 1.5 $\mathrm{mm}$, connivent at apex; staminodes 2 , to $0.7 \mathrm{~mm}$ long, often curled; nectary annular, c. $1 \mathrm{~mm}$ tall, lower side slightly taller, shallowly lobed; pistil to $12.5 \mathrm{~mm}$ long, not projecting beyond the corolla tube, ovary and style pinkish purple, stigma purple, 

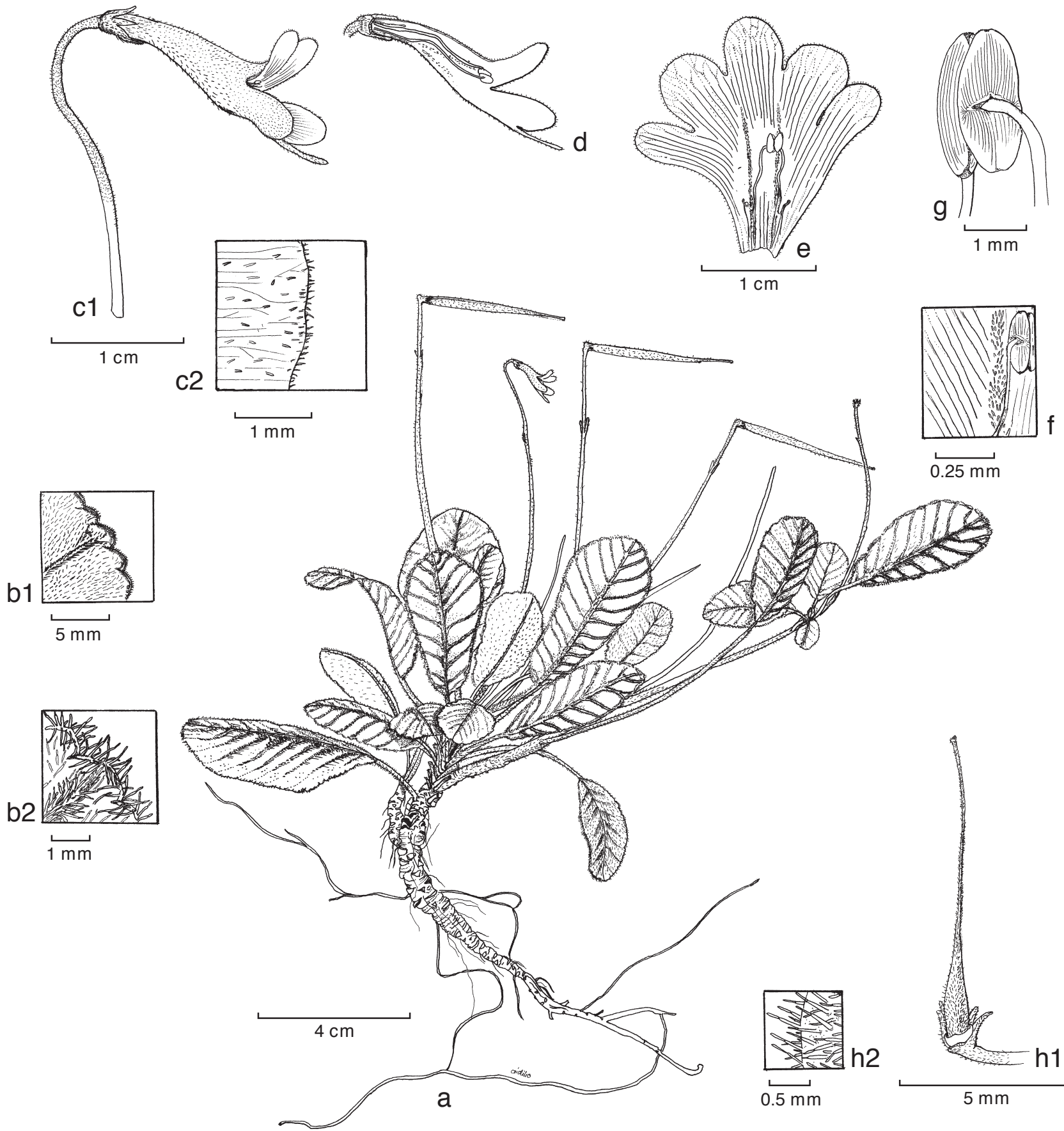

b2

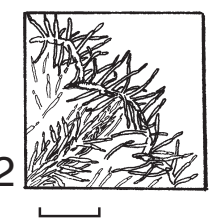

$1 \mathrm{~mm}$

h2

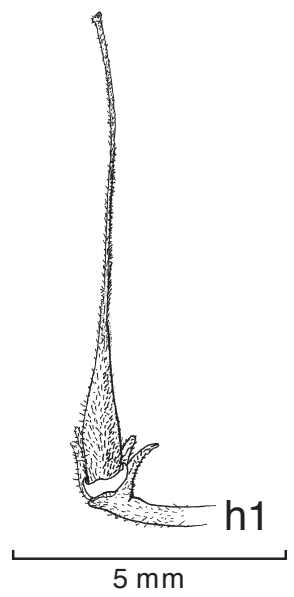

Fig. 1 Codonoboea oreophila Kiew ex. C.L.Lim. a. Habit; b1. lamina margin indumentum beneath; b2. close up of lamina margin indumentum beneath; c1. side view of flower; c2. indumentums of corolla lobe outside; d. side view of flower with part of corolla tube and pistil removed; e. corolla inside, showing nectar guide, stamens and staminoids; f. close-up of nectary guide below stamen; g. side view of anthers; $\mathrm{h} 1$. pistil with part of calyx removed, to reveal nectary at base; h2. close up of pistil indumentum (all Lim et al. FRI 56646, KEP).

Table 1 Diagnostic differences between Codonoboea pumila, C. oreophila and C. rubiginosa.

\begin{tabular}{|c|c|c|c|}
\hline Character & C. pumila & C. oreophila & C. rubiginosa \\
\hline Petiole length $(\mathrm{mm})$ & $(1-1.2) 1.4-2.2(2.8-2.9)$ & $(0.5-) 1.5-2.4(-3.2)$ & $1.5-1.7(9.9-19.5)$ \\
\hline Lamina shape & broad ovate to broad obovate & oblanceolate to oblong & oblong to obovate \\
\hline Lamina length $(\mathrm{cm})$ & $(3.3-3.9) 4.1-4.5(-5.6)$ & $3-4.8(-6)$ & $(3.7-4.9) 5.2-6.8(7.4-11.1)$ \\
\hline Lamina width $(\mathrm{cm})$ & $(1.6-1.9) 2-2.3(-3.6)$ & $1.6-2.2(2.6-3.1)$ & $1.5-2.4(-2.9)$ \\
\hline Lamina base & broad attenuate & $\begin{array}{l}\text { rounded to broadly cuneate, } \\
\text { sometimes cordate, unequal }\end{array}$ & $\begin{array}{l}\text { base broadly acute, } \\
\text { rounded to cordate }\end{array}$ \\
\hline Indumentum of upper leaf surface & appressed & appressed & erect \\
\hline No. flowers per inflorescence & $(1-) 2$ & 1 & $(2-6) 8-12(-22)$ \\
\hline Bract length (mm) & $(0.8-1.6) 2.5-2.8$ & $0.8-1.7$ & $(2.4-2.7) 4.2-4.5$ \\
\hline Bract width (mm) & $0.5-1.1$ & 0.3 & 1.1 \\
\hline Corolla length $(\mathrm{mm})$ & c. 7 & $19-21$ & c. 7 \\
\hline Presence of nectar guides & - & + & - \\
\hline
\end{tabular}


pistil with short eglandular hairs, denser on the ovary, ovary ovoid, c. 4.5 by $1.3 \mathrm{~mm}$, style $7.3 \mathrm{~mm}$ long, stigma discoid, c. 0.4 by $0.4 \mathrm{~mm}$, in life glistening, apex dense papillose. Fruits narrowly cylindrical, slightly quadrangular in cross section, splitting on dorsal side, (2.5-)3-3.5 cm long, $1 \mathrm{~mm}$ thick, dark purplish maroon, style persistent to $0.5-0.7 \mathrm{~mm}$ long. Seeds ovoid, c. 0.3 by $0.2 \mathrm{~mm}$.

Distribution - Endemic in Peninsular Malaysia, known only from Gunung Stong State Park, Kelantan.

Habitat - Mossy ground and mossy base of trees, and on earth banks on ridges in upper montane forest above $1000 \mathrm{~m}$ altitude.

Other specimens examined. KeLANTAN, Gunung Stong State Park - Gunung Stong, Mohd Nur \& Foxworthy SFN 12229 (SING), Symington, FMS 37716 (SING), Kiew, RK 2734 (KEP); ridge to Gunung Tera: Chew FRI 53568 (K, KEP, SING); near Saji Swamp: Yao FRI 55850 (KEP).
Acknowledgements We thank the Ministry of Science, Technology and Innovation Malaysia for funding the fieldwork as part of Flora of Peninsular Malaysia Project (No. 01-04-01-000 Khas 2). This article forms part of the Master of Science degree studies of the first author at the University of Malaya. The first author would like to thank the Training Committee of the Forest Research Institute Malaysia for sponsoring his study and the Institute of Research Management and Monitoring, University of Malaya for the research grant (PS170-2008B). We are grateful to the curators of the BM, Kand SING herbaria, for permission to examine specimens in their care. We thank Dr. J.-F. Veldkamp (L) for translating the diagnosis into Latin and for some critical remarks. We are indebted to Mohd. Aidil Noordin for the illustration.

\section{REFERENCES}

Kiew R. 1992. Five new species of Didymocarpus (Gesneriaceae) from Peninsular Malaysia. Gardens' Bulletin Singapore 44: 23-42.

Kiew R, Lim CL. 2011. Names and new combinations for Peninsular Malaysian species of Codonoboea Ridl. (Gesneriaceae). Gardens' Bulletin Singapore 62, 2: 253-275.

Ridley HN. 1923. Gesneriaceae. Flora Malay Peninsula 2: 495-547. Reeve \& Co., Ltd., London. 